\title{
Irrigation suitability of North Bengal Sugar Mill's effluent and its impact on soil properties
}

\author{
S. S. Tabriz, M. A. Mojid and G. C. L. Wyseure ${ }^{1}$ \\ Department of Irrigation and Water Management, Bangladesh Agricultural University, Mymensingh-2202, \\ Bangladesh, Email: ma_mojid@yahoo.com and ${ }^{1}$ Division of Land and Water Management, Department of Earth and \\ Environmental Sciences, Celestjnenlaan 200E, 3001 Leuven (Heverlee), Belgium
}

\begin{abstract}
The suitability of effluent water (hereafter called wastewater) from North Bengal Sugar Mill (NBSM) for irrigation and its impact on soil properties were evaluated. The quality parameters of wastewater from three different locations of the drainage canal and one freshwater sample from a hand tubewell of the NBSM complex were determined. The major physico-chemical and hydraulic properties of the wastewater affected and unaffected soils from West Baiddanathpur village (hereafter referred to as site 1) and East Baiddanathpur village (hereafter referred to as site 2) were determined. The electrical conductivity (EC) and $\mathrm{pH}$ of the wastewater were $0.78-1.05 \mathrm{dS}^{-1}$ and $6.6-6.95$, respectively. The wastewater was richer than the freshwater in terms of nitrogen $\left(15.8-24.7 \mathrm{mg} \mathrm{I}^{-1}\right)$ and phosphorous (5.2-6.0 $\left.\mathrm{mg} \mathrm{I}^{-1}\right)$ contents. The iron $\left(0.37-0.49 \mathrm{mg} \mathrm{I}^{-1}\right)$, manganese $\left(0.3-0.9 \mathrm{mg} \mathrm{I}^{-1}\right)$ and boron $\left(0.43-0.51 \mathrm{mg} \mathrm{I}{ }^{-1}\right)$ concentrations were higher in the wastewater than in the freshwater. The biological oxygen demand (BOD) and chemical oxygen demand (COD) of the wastewater was 183-309 $\mathrm{mg} \mathrm{I}^{-1}$ and 196-685 $\mathrm{mg} \mathrm{I}^{-1}$, respectively. All these chemical constituents decreased with the flow path of the wastewater. Temperature of the wastewater at the head end of the disposal canal was $39.5^{\circ} \mathrm{C}$ that decreased to the ambient temperature at the downstream. The BOD, COD and temperature of the wastewater exceeded the threshold values for irrigation and, therefore, this water would not be suitable for irrigation without treatment. The wastewater elevated the EC and reduced the $\mathrm{pH}$ of soil. It however improved soil fertility by improving the phosphorous, potassium, sulphur and organic matter contents. It also elevated the porosity and reduced the bulk density of soil. The soil-water content at field capacity and the saturated hydraulic conductivity increased due to the effect of wastewater.
\end{abstract}

Keywords: Sugar mill, Effluent, Irrigation, Soil properties

\section{Introduction}

The pressure on irrigated agriculture is increasing day-by-day to ensure food security. The irrigation water in Bangladesh is a limited resource. A dramatic increase in demand of water for dry season irrigation causes an acute shortage of water in many parts of the country. So, additional water source(s) for irrigation may be an important solution to this problem. Pereira et al. (2002) suggested use of treated wastewater when freshwater is scarce. At the advent of increased scarcity of freshwater in Bangladesh, wastewater warrants attention to its use for irrigation. When irrigation is done by wastewater, it not only meets the demand of water, but may supply nutrients to soils to be used by crops.

There are 15 sugar mills in Bangladesh, established in the rural areas. They produce sugar as well as large amount of wastewater. The sugar mills, on an average, generate one cubic meter of wastewater per ton of crushed cane (Agrawal, undated). The wastewater comes mainly from the cooling system and floor washing. Leakage in valves and glands of the pipelines adds sugarcane juice, syrup and molasses to the effluent. November-April is the time for sugar production, and it is also the time for irrigation of sugarcane and most rabi crops. This can make sugar production more profitable. There might have however some negative impact of irrigation by wastewater on environment and soil physicochemical properties. So, managing this water for irrigation use in a sustainable way can be a good venture.

The quality of irrigation water has great importance since many soil properties may be affected. The important quality parameters of wastewater from an agricultural point of view (Kandiah, 1990) are: physical properties such as total dissolved solids (TDS), electrical conductivity, temperature, color/turbidity, hardness and sediments, and chemical properties such as acidity/basicity, type and concentration of cations and anions (calcium, magnesium, sodium, carbonate, bicarbonate, chloride, sulphate, sodium adsorption ratio, boron, trace metals, nitrate-nitrogen and potassium). The discharge of 
sugar mill's wastewater to surface water bodies with a high TDS adversely affects aquatic life, renders the receiving water unfit for domestic use and reduces or even damages crop yield if used for irrigation (ETPI, 2001). However, the minimally treated wastewater can be used to irrigate the neighboring sugarcane fields, thus making the sugar production process a close-loop-system that utilizes its own wastes as inputs. There are however possibilities of accumulation of sludge in the irrigated soils (UNESCAP, 1982). Before any formal attempt for sustainable irrigation with sugar mills' wastewater in Bangladesh, the quality of the water as well as its impact on soils need to be evaluated. This study was therefore designed (i) to evaluate the important properties of the NBSM's wastewater and (ii) to investigate the physicochemical and hydraulic properties of the soil affected by the wastewater.

\section{Materials and Methods}

\section{Determination of water quality parameters}

Three wastewater samples were collected at a time from the wastewater disposal canal of the NBSM at Natore: one at the head end of the canal near the mill, one at $1.5 \mathrm{~km}$ and the other at $6 \mathrm{~km}$ downstream from the canal head end. These samples were designated by WW-1, WW-2 and WW-3, respectively. One freshwater sample, collected from a hand tubewell at the NBSM complex, was designated by FW. The water samples were collected three times during the mill operating period (mid-November to mid-March) of 2010-2011. The samples were collected in $500 \mathrm{ml}$ inert and opaque plastic bottles that were washed with distilled water first and with the water to be sampled immediately before collection of the samples. The temperature of the wastewater at the three locations of the canal was measured with a digital thermometer. After collection, the water samples were transferred to laboratory and stored at $4{ }^{\circ} \mathrm{C}$ for analysis within $8-10 \mathrm{~h}$ of collection.

Nitrate-nitrogen $\left(\mathrm{NO}_{3}-\mathrm{N}\right)$, nitrite-nitrogen $\left(\mathrm{NO}_{2}-\mathrm{N}\right)$, ammonia-nitrogen $\left(\mathrm{NH}_{3}-\mathrm{N}\right)$, phosphorous $(P)$, boron $(B)$, zinc $(\mathrm{Zn})$, manganese $(\mathrm{Mn})$ and iron $(\mathrm{Fe})$ contents of the freshwater and wastewater samples were measured by a DR/890 colorimeter (Hach Co., USA). The $\mathrm{pH}$ and electrical conductivity of the samples were measured by an $\mathrm{EC} / \mathrm{pH}$ meter. The biological oxygen demand (BOD), which is the amount of oxygen required by microorganisms to stabilize biologically decomposable organic matter under aerobic condition, indicates the amount of biologically degradable organic matter in the wastewater. The BOD of the wastewater samples after 5 days (recognized standard known as $\mathrm{BOD}_{5}$ ) was measured with $\mathrm{BOD}$ sensors and incubator (VELP SCIENTIFICA, Italy). The chemical oxygen demand (COD) measures the amount of oxygen required for oxidation of organic compounds present in wastewater by means of chemical reactions involving oxidizing substances such as potassium dichromate and potassium permanganate. The wastewater samples were shaken vigorously and the required quantity of each water sample was mixed with a COD reagent in separate vials. The vials were heated at $200^{\circ} \mathrm{C}$ for $2 \mathrm{~h}$ in a COD reactor for digestion. The samples were cooled at room temperature and their COD's were measured by colorimetric method.

\section{Determination of soil properties}

Soil samples, both wastewater affected and unaffected, were collected from two locations of the sugar mill area: West Baiddanathpur village (site 1) and East Baiddanathpur village (site 2). The site 1 was approximately half a kilometer downstream and the site 2 was $1.5 \mathrm{~km}$ downstream from the head end of the wastewater disposal canal. The samples were transferred to the laboratory, dried in air and sieved through a 2-mm square mesh sieve. Sub-samples were prepared from these samples that were stored in polyethylene bags for analysis. Three repacked (disturbed) samples for each location were prepared in core samplers of $5 \mathrm{~cm}$ diameter and $5 \mathrm{~cm}$ height. Three undisturbed soil samples were also collected from each location in the core samplers.

The fractions of sand, silt and clay in the soils were determined by Hydrometer Method. By plotting the percentage values of these fractions on the Marshall's triangular co-ordinate, the textural classes of the soils were determined (Table 1). The $\mathrm{EC}$ and $\mathrm{pH}$ of the soils were determined by measuring them in the 
saturation extract of the soils by a combine $\mathrm{EC} / \mathrm{pH}$ meter at $25^{\circ} \mathrm{C}$. The saturated hydraulic conductivity $\left(K_{s}\right)$ of the six core samples ( 3 undisturbed and 3 disturbed) was determined by Constant Head Method; $K_{\mathrm{s}}$ was calculated by $K_{s}=V / t i A$ where, $Q$ is the flow rate of water through the soil, $V$ is the volume of water collected in time $t, A$ is the cross-sectional area of the soil core, $i=\Delta h / L$ is the hydraulic gradient, $\Delta h$ is the difference in hydraulic head under which water flows through the sample and $L$ is the length of the core sample. Accounting for the volume of water that drained from a saturated soil core by gravity in $48 \mathrm{~h}$ the gravitational water was calculated from the ratio of the volume of water drained to the volume of soil and expressed as a percentage. The volume of the soil was calculated from the diameter and height of the core sampler. The water retained by the soil was determined by the difference in weight of the sample after the gravitational water was drained out and that of the oven dry sample. The field capacity was then calculated from the ratio of the volume of water retained to the volume of the soil and expressed as a percentage. After measuring the gravitational water and field capacity, the porosity was calculated by adding the gravitational water and field capacity with the assumption of full saturation of the soil samples. The bulk density was calculated by the ratio of the mass of soil to the total volume of the soil. Soil-water retentions in the experimental soils were determined by using a Sand Box (Eijkelkamp, Agrisearch Equipment, The Netherlands) for low suction ( $<100 \mathrm{~cm}$ of water) and a pressure plate apparatus (Soil Moisture Equipment Corp., Santa Barbara, Ca., USA.) for high suctions $(100-10000 \mathrm{~cm}$ of water). The total nitrogen, organic carbon, available phosphorus and sulphur, and exchangeable sodium and potassium contents of the soils were determined in the Humboldt Soil Testing Laboratory of the Department of Soil Science, Bangladesh Agricultural University, Mymensingh.

Table 1. The percentage of sand, silt and clay content along with the textures of the wastewater affected and unaffected soils at site 1 and site 2

\begin{tabular}{|l|l|c|c|c|l|}
\hline Location & Pollution status & \% Sand & \% Silt & \% clay & Soil texture \\
\hline site 1 & affected & 22.96 & 56.84 & 20.20 & silt loam \\
\hline site 2 & affected & 8.96 & 65.84 & 25.20 & silt loam \\
\hline site 1 & unaffected & 12.96 & 51.84 & 35.20 & silty clay loam \\
\hline site 2 & unaffected & 16.96 & 59.84 & 23.20 & silt loam \\
\hline
\end{tabular}

\section{Results and Discussion}

\section{Wastewater quality}

EC and pH: The electrical conductivity of wastewater, EC, varied from $0.78 \mathrm{dS} \mathrm{m}^{-1}$ to $1.05 \mathrm{dS} \mathrm{m}^{-1}$ (Table 2); it was $1.05 \mathrm{dS} \mathrm{m}^{-1}$ at the head end of the drainage canal and $0.78 \mathrm{dS} \mathrm{m}^{-1}$ at $6 \mathrm{~km}^{-10 w n s t r e a m}$. The reduction of EC with the length of flow path was due to diffusive transfer of electrolytes into the canal bed as well as their adsorption with suspended materials in the wastewater. The recommended threshold (TV) EC is $0.70 \mathrm{dS} \mathrm{m}^{-1}$ (FAO, 1992), $0.75 \mathrm{dS} \mathrm{m}^{-1}$ (ADB, 1994) or $1.2 \mathrm{dS} \mathrm{m}^{-1}$ (GOB, 1997). So, based on Bangladesh standard, the sugar mill's wastewater would not pose any adverse effect if used for irrigation. The $\mathrm{pH}$ of wastewater, $6.6-6.95$ (Table 2), although indicated mild acidity did not exceed the permissible limit for irrigation: 6.0 - 8.4 (Ayers and Westcot, 1985), 6.5 - 8.5 (FAO, 1992), 6.0-8.5 (ADB, 1994) or 6.0 -9.0 (GOB, 1997).

Macronutrients: Nitrogen $(\mathrm{N})$ exists in wastewater as nitrate, ammonia, organic nitrogen and nitrite. The sum of all these forms is known as the total nitrogen (Kadlec and Knight, 1996). The concentration of nitrate nitrogen $\left(\mathrm{NO}_{3}-\mathrm{N}\right)$, nitrite nitrogen $\left(\mathrm{NO}_{2}-\mathrm{N}\right)$ and ammonia nitrogen $\left(\mathrm{NH}_{3}-\mathrm{N}\right)$ were within the range of $15.00-24.13,0.229-0.292$ and $0.32-0.57 \mathrm{mg} \mathrm{l}^{-1}$, respectively. The corresponding values for these forms of $\mathrm{N}$ in freshwater were 2.26, 0.064 and $1.05 \mathrm{mg} \mathrm{l}^{-1}$ (Table 2). The nitrate nitrogen was below the FAO (1992) recommended threshold value $\left(30 \mathrm{mg} \mathrm{l}^{-1}\right)$ in all samples. Taking into account the $\mathrm{N}$ content of the sugar mill's wastewater, it is affirmed that this water has a good potential for using in irrigation, preferably with a pre-treatment. 
The phosphorus $(\mathrm{P})$ content in wastewater at different locations of the wastewater disposal canal ranged from 5.2 to $6.0 \mathrm{mg} \mathrm{l}^{-1}$ and in the fresh water it was $0.9 \mathrm{mg} \mathrm{l}^{-1}$ (Table 2). Phosphoric acid was used in sugar processing. A fraction of this acid was released to wastewater through washing and other processes with an ensuing increase in $P$ in the wastewater. A phosphorus content of $15 \mathrm{mg} \mathrm{I}^{-1}$ in wastewater is considered the threshold limit for irrigation (GOB, 1997) and $2.0 \mathrm{mg} \mathrm{l}^{-1}$ as permissible for discharging into surface water bodies that does not have substantial problems with high levels of nutrients (Shahinasi and Kashuta, 2008). So, based on P content, the wastewater of the NBSM would be suitable for irrigation.

Table 2. The average quality parameters of North Bengal Sugar Mill's wastewater and local freshwater along with their threshold values (TV) for use in irrigation

\begin{tabular}{|c|c|c|c|c|c|c|c|c|c|c|c|c|}
\hline \multirow[t]{2}{*}{ Sample } & \multirow{2}{*}{$\begin{array}{c}E C \\
\left(\mathrm{dS} \mathrm{m}^{-1}\right)\end{array}$} & \multirow[t]{2}{*}{$\mathrm{pH}$} & \multicolumn{10}{|c|}{ Concentration of different chemical constituents $\left(\mathrm{mg} \mathrm{l}^{-1}\right)$ in water } \\
\hline & & & $\mathrm{NO}_{3}-\mathrm{N}$ & $\mathrm{NO}_{2}-\mathrm{N}$ & $\mathrm{NH}_{3}-\mathrm{N}$ & $P$ & $\mathrm{Fe}$ & $\mathrm{Mn}$ & $\mathrm{Zn}$ & $B$ & BOD & COD \\
\hline$\overline{F W}$ & 0.60 & 6.90 & 2.26 & 0.064 & 1.05 & 0.9 & 0.36 & 0.50 & ND & 0.14 & - & - \\
\hline WW-1 & 1.03 & 6.60 & 15.0 & 0.229 & 0.57 & 5.2 & 0.43 & 0.70 & ND & 0.49 & 309 & 685 \\
\hline WW-2 & 1.05 & 6.95 & 19.84 & 0.257 & 0.51 & 6.0 & 0.49 & 0.90 & $\mathrm{ND}$ & 0.43 & 311 & 699 \\
\hline WW-3 & 0.78 & 6.83 & 24.13 & 0.292 & 0.32 & 5.7 & 0.37 & 0.30 & ND & 0.51 & 183 & 196 \\
\hline TV & $1.2 \mathrm{I}^{*}$ & 6-9 ग & $30.0^{* *}$ & $\mathrm{~N} / \mathrm{A}$ & $\mathrm{N} / \mathrm{A}$ & $15 \pi$ & $1-2 \pi$ & $5.0 \mathrm{~T}$ & $10 \pi$ & $2.0 \mathrm{~T}$ & $10 \pi$ & $\mathrm{N} / \mathrm{A}$ \\
\hline
\end{tabular}

ND: not detectable. N/A: Not available

II Proposed irrigation water quality standards for Bangladesh according to GOB (1997).

** Proposed irrigation water quality standards for Bangladesh according to FAO (1992).

* This is an average value; actual threshold value is dependent on sodium adsorption ratio (SAR) as: for the SAR value of $0-3,3-6,6-12,12-20$ and $20-40$, the corresponding threshold value of $E C\left(\mathrm{dS} \mathrm{m}^{-1}\right)$ is $0.2,0.3,0.5$, 1.3 and 2.9 .

Micronutrients: The iron ( $\mathrm{Fe})$ content of the wastewater ranged from 0.37 to $0.49 \mathrm{mg} \mathrm{I}^{-1}$ and that of the freshwater was $0.36 \mathrm{mg} \mathrm{l}^{-1}$ (Table 2). Considering the maximum permissible $\mathrm{Fe}$ in irrigation water, $5.0 \mathrm{mg}$ $\mathrm{I}^{-1}(\mathrm{FAO}, 1992)$ or $1-2 \mathrm{mg} \mathrm{I}^{-1}(\mathrm{GOB}, 1997)$, the wastewater at the three sampling locations was found suitable for irrigation.

The manganese $(\mathrm{Mn})$ content of wastewater varied from 0.3 to $0.9 \mathrm{mg} \mathrm{I}^{-1}$ and that of freshwater was 0.50 $\mathrm{mg} \mathrm{I}^{-1}$ (Table 2). The concentration of $\mathrm{Mn}$ in wastewater increased since large quantity of cooling water was evaporated during its temperature reduction by spraying into air. The maximum allowable limit of $\mathrm{Mn}$ in irrigation water is $0.20 \mathrm{mg} \mathrm{l}^{-1}$ (FAO, 1992) or $5 \mathrm{mg} \mathrm{l}^{-1}$ (GOB, 1997). The Mn contents both in the wastewater and freshwater were suitable for irrigation according to Bangladesh standard. The concentration of zinc $(\mathrm{Zn})$ in the wastewater and freshwater was not detectable (Table 2) with the DR/890 colorimeter (Hach Co., USA), which could detect $\mathrm{Zn}$ up to $0.01 \mathrm{mg} \mathrm{I}^{-1}$. The FAO (1992) recommended maximum permissible limit of $\mathrm{Zn}$ in irrigation water is $2.00 \mathrm{mg} \mathrm{l}^{-1}$ and that by GOB (1997) is $10 \mathrm{mg} \mathrm{l}^{-1}$. So, considering the $\mathrm{Zn}$ content, there was no restriction to use the sugar mill's wastewater in irrigation. The boron (B) content in the wastewater was in the range of $0.43-0.51 \mathrm{mg} \mathrm{l}^{-1}$ and, in the freshwater it was $0.14 \mathrm{mg} \mathrm{I}^{-1}$. The freshwater used for cooling, which ultimately came out as wastewater, also contained $\mathrm{B}$ and, due to evaporation during temperature reduction, its concentration increased. B in sugar mill's wastewater as well as in freshwater was however within the FAO (1992) recommended suitable value of $0.7 \mathrm{mg} \mathrm{l}^{-1}$ and GOB (1997) recommended value of $2.0 \mathrm{mg}^{-1}$ for irrigation; the maximum allowable limit of $B$ for irrigation is $3.00 \mathrm{mg} \mathrm{I}^{-1}$.

BOD and COD: The BOD and COD of the wastewater ranged from 183 to $309 \mathrm{mg} \mathrm{l}^{-1}$ and 196 to 685 $\mathrm{mg} \mathrm{I}^{-1}$, respectively (Table 2). The high BOD and COD values of the wastewater implied that it contained large amount of biodegradable materials. The BOD decreased by 1.69 times and COD by 3.49 times as the wastewater passed a distance of $6 \mathrm{~km}$. The BOD range of the wastewater was much higher than the ADB (1994) and GOB (1997) proposed BOD of $10 \mathrm{mg}^{-1}$ in irrigation water quality standards for Bangladesh. Therefore, a pre-treatment of the wastewater to reduce its organic load is required to bring down the BOD and COD. 
Temperature: The temperature of irrigation water beyond the critical limit has adverse effect on crops. The temperature of the sugar mill's wastewater at the head end of the disposal canal was the maximum at $39.5^{\circ} \mathrm{C}$ and this water cooled to ambient temperature as it traveled $1-2 \mathrm{~km}$ from the head end of the canal. The suitable temperature range of water for irrigation is $20-30^{\circ} \mathrm{C}(\mathrm{GOB}, 1997)$. The high temperature of the wastewater at the head end restricts its use for irrigation since a high temperature difference with ambient temperature creates thermal shock both to crops and human working with the water.

\section{Impacts of wastewater on soil}

Soil physical properties: The average bulk density decreased from 1.30 to $1.02 \mathrm{~g} \mathrm{~cm}^{-3}$ for the disturbed soil and from 1.38 to $1.12 \mathrm{~g} \mathrm{~cm}^{-3}$ for the undisturbed soil at site 1 (Table 3). At site 2, the average bulk density decreased from 1.27 to $1.17 \mathrm{~g} \mathrm{~cm}^{-3}$ for the disturbed soil and from 1.27 to $1.11 \mathrm{~g} \mathrm{~cm}^{-3}$ for the undisturbed soil. The wastewater contained considerable quantity of ash and organic matters such as bagasse, press mud, molasses, etc., which accumulated in the soil over time and were responsible for the reduction of the bulk density. Vogeler (2009) also obtained reduced bulk density due to the effect of wastewater. The porosities of the wastewater affected and unaffected soils, both under disturbed and undisturbed conditions, at the two locations are listed in Table 3. Due to the effect of wastewater, porosity increased by $10.5 \%$ at site 1 and $4.7 \%$ at site 2 for the disturbed soil. For the undisturbed soil, it increased by $9.8 \%$ at site 1 and $5.9 \%$ at site 2 . The larger increase in porosity both for the disturbed and undisturbed soil at site 1 than at site 2 was due to the higher organic matter and ash content in the wastewater at site 1 since this site is at the upstream location. The organic matters and ash were much higher in wastewater near the head end of the disposal canal (site 1) that caused high porosity by their higher accumulation in the soil.

Table 3. The bulk density and porosity of wastewater-unaffected and wastewater-affected soils under disturbed and undisturbed conditions at sites 1 and 2

\begin{tabular}{|l|c|c|c|c|c|}
\hline Soil structure & Location & \multicolumn{2}{|c|}{ Bulk density $\left(\mathrm{g} \mathrm{cm}^{-3}\right)$} & \multicolumn{2}{c|}{ Porosity $(\%)$} \\
\cline { 3 - 6 } & & unaffected & unaffected & affected & affected \\
\hline \multirow{2}{*}{ disturbed } & site 1 & 1.30 & 1.30 & 51.31 & 61.78 \\
\cline { 2 - 6 } & site 2 & 1.27 & 1.27 & 51.26 & 55.96 \\
\hline \multirow{2}{*}{ undisturbed } & site 1 & 1.38 & 1.38 & 43.98 & 53.75 \\
\cline { 2 - 6 } & site 2 & 1.27 & 1.27 & 48.44 & 54.32 \\
\hline
\end{tabular}

Soil hydraulic properties: The gravitational water and field capacity of the wastewater affected and unaffected soils, under both disturbed and undisturbed conditions are compared in Table 4 for the sites 1 and 2. In the wastewater-affected soil, the gravitational water increased by $8.31 \%$ at site 1 and $1.36 \%$ at site 2 for the disturbed soil. For the undisturbed soil, it increased by $4.0 \%$ at site 1 and $0.21 \%$ at site 2 . The field capacity increased by $2.16 \%$ for the disturbed soil and $5.77 \%$ for the undisturbed soil at site 1 . At site 2, it increased by $3.34 \%$ for the disturbed soil and $5.67 \%$ for the undisturbed soil. The accumulation of organic matter and ash improved soil structure and consequently raised the porosity of soil. The improved structure of the wastewater-affected soil also raised the saturated hydraulic conductivity, $K_{\mathrm{s}}$. The average $K_{\mathrm{s}}$ increased from 0.53 to $0.89 \mathrm{~cm} \mathrm{~h}^{-1}$ for the disturbed soil and from 0.14 to $0.87 \mathrm{~cm} \mathrm{~h}^{-1}$ for the undisturbed soil at site 1 (Table 4). At site $2, K_{\mathrm{s}}$ increased from 0.53 to $0.58 \mathrm{~cm} \mathrm{~h}^{-1}$ for the disturbed soil and from 0.34 to $0.69 \mathrm{~cm} \mathrm{~h}^{-1}$ for the undisturbed soil.

Figs. 1 and 2 illustrate the soil-water retention curves of the disturbed and undisturbed soils at site 1 and site 2, respectively to compare the effects of wastewater on the soil in terms of water holding capacity at different suctions. Due to the effect of wastewater, the water holding capacity of the soil increased both for the disturbed and undisturbed conditions at the two sites. The wastewater contained organic and inorganic substances that improved soil structure and, consequently, increased the porosity as well as the water holding capacity of the wastewater affected soils. Besides this, the wastewater contained various electrolytes and fine particles, which deposited in the soil micropores with a consequent relatively reduced water holding capacity of the wastewater affected soils at higher suctions. Dawes and Goonetilleke (2004) and Tarenitzky et al. (1999) also reported increased soil-water content due to the effects of wastewater. 
Table 4. The gravitational water, field capacity and saturated hydraulic conductivity of wastewater unaffected and affected soils at sites 1 and 2

\begin{tabular}{|l|c|l|c|c|c|}
\hline Soil structure & Location & Pollution status & $\begin{array}{c}\text { Gravitational } \\
\text { water (\%) }\end{array}$ & $\begin{array}{c}\text { Field capacity } \\
(\%)\end{array}$ & $\begin{array}{c}\text { Saturated hydraulic } \\
\text { conductivity }\left(\mathrm{cm} \mathrm{h}^{-1}\right)\end{array}$ \\
\hline \multirow{3}{*}{ disturbed } & \multirow{2}{*}{ site 1 } & unaffected & 5.36 & 45.95 & 0.532 \\
\cline { 3 - 6 } & \multirow{2}{*}{ site 2 } & affected & 13.67 & 48.11 & 0.889 \\
\cline { 3 - 6 } & & unaffected & 7.83 & 43.43 & 0.533 \\
\hline \multirow{3}{*}{ undisturbed } & \multirow{2}{*}{ site 1 } & affected & 9.19 & 46.77 & 0.580 \\
\cline { 3 - 6 } & \multirow{2}{*}{ site 2 } & unaffected & 4.22 & 39.76 & 0.143 \\
\cline { 3 - 6 } & & affected & 8.22 & 45.53 & 0.873 \\
\cline { 3 - 6 } & & anffected & 7.99 & 40.45 & 0.338 \\
\hline
\end{tabular}

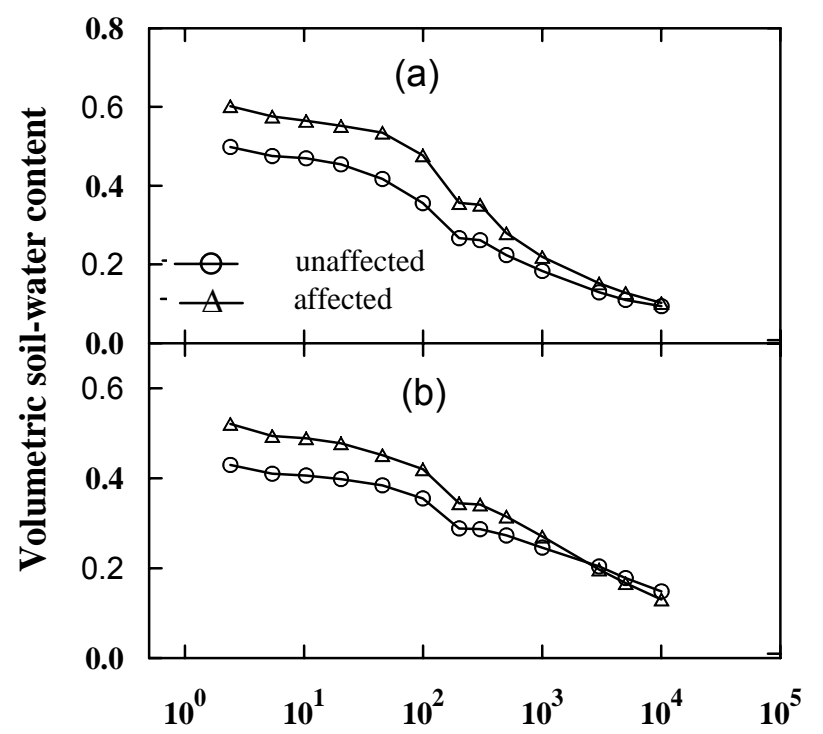

Suction head, cm of water

Fig. 1. Soil-water retention curves for wastewater unaffected and affected (a) disturbed and (b) undisturbed soils of site 1

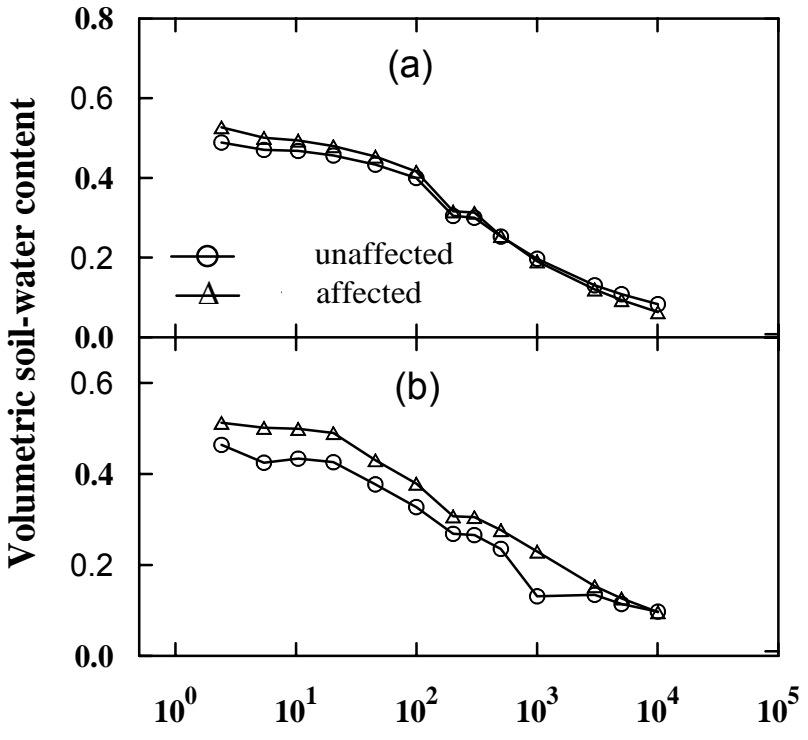

Suction head, cm of water

Fig. 2. Soil-water retention curves for wastewater unaffected and affected (a) disturbed and (b) undisturbed soils of site 2

Soil chemical properties: The wastewater contained various dissolved organic and inorganic substances, which elevated the electrolyte content of the soils with a consequent increase in their electrical conductivity. The EC of the wastewater affected soil was $0.53 \mathrm{dS} \mathrm{m}^{-1}$ at site 1 and $0.38 \mathrm{dS} \mathrm{m}^{-1}$ at site 2 (Table 5). The EC increased by $306 \%$ and $233 \%$ in soil due to the effect of wastewater at site 1 and site 2, respectively. Friedel et al. (2000) and Saleh et al. (2009) also found similar results. A soil with an $\mathrm{EC}$ of the saturation extract more than $4 \mathrm{dS} \mathrm{m}^{-1}$ at $25^{\circ} \mathrm{C}$, an exchangeable sodium percentage of less than 15 and $\mathrm{pH}$ of the saturated paste of less than 8.5 is considered saline (Michael, 1985). So, the sugar mill's wastewater affected and unaffected soils were non-saline and suitable as agricultural soil. 
Table 5. Some chemical properties of wastewater unaffected and affected soils at sites 1 and 2

\begin{tabular}{|c|l|c|c|c|c|c|c|c|c|}
\hline Location & $\begin{array}{l}\text { Pollution } \\
\text { status }\end{array}$ & $\begin{array}{c}\mathrm{EC} \\
\left(\mathrm{dS} \mathrm{m}^{-1}\right)\end{array}$ & $\mathrm{pH}$ & $\begin{array}{c}\text { Total-N } \\
(\%)\end{array}$ & $\begin{array}{c}\mathrm{P} \\
\left(\mathrm{mg} \mathrm{l}^{-1}\right)\end{array}$ & $\begin{array}{c}\mathrm{K} \\
\left(\mathrm{mg} \mathrm{l}^{-1}\right)\end{array}$ & $\begin{array}{c}\mathrm{S} \\
\left(\mathrm{mg} \mathrm{l}^{-1}\right)\end{array}$ & $\begin{array}{c}\mathrm{Na} \\
\left(\mathrm{mg} \mathrm{l}^{-1}\right)\end{array}$ & $\begin{array}{c}\mathrm{OC} \\
(\%)\end{array}$ \\
\hline site 1 & unaffected & 0.130 & 6.84 & 0.134 & 12.64 & 99.63 & 1.38 & 247.22 & 0.683 \\
\hline site 1 & affected & 0.528 & 6.55 & 0.252 & 38.76 & 227.73 & 19.85 & 116.27 & 2.140 \\
\hline site 2 & unaffected & 0.114 & 6.70 & 0.162 & 15.39 & 87.43 & 1.80 & 93.91 & 0.987 \\
\hline site 2 & affected & 0.380 & 6.56 & 0.168 & 39.68 & 183 & 43.04 & 98.38 & 1.138 \\
\hline
\end{tabular}

The soil pH decreased to 6.55 from 6.84 at site 1 and to 6.56 from 6.70 at site 2 due to the effect of sugar mill's wastewater (Table 5). The $\mathrm{pH}$ of wastewater was the minimum at the head end of the wastewater disposal canal that caused lower $\mathrm{pH}$ of the wastewater-affected soil at site 1. Phosphoric acid and sulphur, used in the sugar mill during sugar production, reduced the $\mathrm{pH}$ of wastewater and, consequently, the wastewater-affected soil. Generally, 6-7 soil $\mathrm{pH}$ is considered suitable for adequate availability of nutrients in soils. Thus, the $\mathrm{pH}$ of wastewater-affected soils was optimum for sustainable soil fertility and crop productivity.

The dissolved and suspended organic substances in the wastewater accumulated in the soil that raised the total $\mathrm{N}$ content to $0.252 \%$ from $0.134 \%$ and to $0.168 \%$ from $0.126 \%$ in the wastewater-affected soil at site 1 and site 2, respectively (Table 5). The larger increase in $\mathrm{N}$ at site 1 than at site 2 was due to the higher organic matter content in the wastewater at site 1 than at site 2. So, the wastewater-affected soil was richer than the wastewater-unaffected soil in terms of $\mathrm{N}$ content.

The considerable quantity of $\mathrm{P}$ in the wastewater caused an increase of $\mathrm{P}$ in the wastewater-affected soil, showing an increase to $38.76 \mathrm{mg} \mathrm{l}^{-1}$ from $12.64 \mathrm{mg} \mathrm{l}^{-1}$ at site 1 and to $39.68 \mathrm{mg} \mathrm{l}^{-1}$ from $15.39 \mathrm{mg} \mathrm{l}^{-1}$ at site 2 (Table 5). Similar results were also reported by Saleh et al. (2009). The wastewater contained large quantity of fly ash, which accumulated in the soil and consequently raised its $\mathrm{K}$ content. The $\mathrm{K}$ content of soils (Table 5) increased to $227.7 \mathrm{mg} \mathrm{I}^{-1}$ from $99.6 \mathrm{mg} \mathrm{l}^{-1}$ at site 1 and to $183 \mathrm{mg} \mathrm{l}^{-1}$ from $87.4 \mathrm{mg} \mathrm{I}^{-1}$ at site 2. Saleh et al. (2009) and Friedel et al. (2000) also reported increased K content of soil due to the effect of wastewater.

The wastewater also raised the sulphur (S) content in the wastewater-affected soil showing $19.85 \mathrm{mg} \mathrm{I}^{-1}$ from $1.38 \mathrm{mg} \mathrm{I}^{-1}$ at site 1 and to $43.04 \mathrm{mg} \mathrm{I}^{-1}$ from $1.80 \mathrm{mg} \mathrm{l}^{-1}$ at site 2 . Sulphur was used for refining juice in the sugar mill and a part of it entered the wastewater that elevated $S$ content in the wastewateraffected soil. As an impact of wastewater, the $\mathrm{Na}$ of the wastewater-affected soil decreased to $116.3 \mathrm{mg}$ $\mathrm{I}^{-1}$ from $247.2 \mathrm{mg} \mathrm{l}^{-1}$ at site 1, but at site 2 it increased to $98.4 \mathrm{mg} \mathrm{I}^{-1}$ from $93.9 \mathrm{mg} \mathrm{l}^{-1}$. The larger EC of wastewater near the head end of the wastewater disposal canal was responsible for the larger $\mathrm{Na}$ content of the soil at site 1 than at site 2. In terms of $\mathrm{Na}$ effect, the sugar mill's wastewater was more harmful for the soil at site 1 than at site 2 .

The organic carbon (OC\%) in the wastewater unaffected and affected soils was $0.683 \%$ and $2.14 \%$, respectively at site 1 and $0.987 \%$ and $1.138 \%$, respectively at site 2 . Saleh et al. (2009) and Friedel et al. (2000) also found increased OC\% in wastewater-affected soil. Organic matter, which is calculated as 1.73 times of OC influences physical, chemical and biological properties of soils. So, the use of sugar mill's wastewater for irrigation would increase soil fertility by increasing organic matter content.

\section{Conclusion}

The effluent/wastewater of the North Bengal Sugar Mill had high biological oxygen demand (BOD) and chemical oxygen demand (COD), which were harmful to the environment if the wastewater is discharged into surface water bodies. Higher temperature (at the head end of the disposal canal) along with higher BOD and COD rendered the wastewater unsuitable for irrigation. The wastewater however contained considerable quantity of plant nutrients such as nitrogen, phosphorus and potassium along with some micronutrients such as zinc and boron. The wastewater raised the electrical conductivity but reduced the 
$\mathrm{pH}$ of soil. The wastewater, by raising phosphorous, potassium, sulphur and organic matter contents in the soil improved soil fertility. It also caused an increase in the porosity but decrease in the bulk density of soil. There were some positive impacts of the sugar mill's wastewater on soil hydraulic properties; the gravitational water, field capacity and saturated hydraulic conductivity increased due to the effect of wastewater.

\section{Acknowledgement}

This study was executed under the Sponsored Public Goods Research (SPGR) project of the Bangladesh Agricultural Research Council (BARC) and 'VLIR-Own Initiatives' program with the Bangladesh Agricultural University at Mymensingh. The authors gratefully acknowledge the funding support of the BARC and Belgian Directorate General for Development Cooperation (DGDC) through the "Vlaamse Interuniversitaire Raad' (VLIR; Flemish Interuniversity Council).

\section{References}

ADB (Asian Development Bank). 1994. Training Manual for Environment, Asian Development Bank.

Agrawal, G.D. undated. Waste management and pollution control for Bangladesh sugar factories and distilleries. Unpublished lecture note to Bangladesh Sugarcane Research Institute (BSRI), Ishurdi.

Ayers, R.S. and Westcot, D.W. 1985. Water Quality for Agriculture. FAO Irrigation and Drainage paper, 29: 8-96.

Dawes, L. and Goonetilleke, A. 2004. Assessing changes in soil physical and chemical properties under long-term effluent disposal. Proceedings of the $10^{\text {th }}$ National Symposium on Individual and Small Community Sewage System, Sacremento, California, pp.349-357.

ETPI (Environmental Technology Program for Industry). 2001. Environmental report on sugar sector. Monthly Environ. News 5, Issue 7 (July): 11-27.

FAO (Food and Agriculture Organization). 1992. Wastewater treatment and use in agriculture. M.B. Pescod (ed.), FAO Irrigation and Drainage paper 47, FAO, Rome. 125p.

Friedel, J.K., Langer, T., Siebe, C. and Stahr, K. 2000. Effects of long-term wastewater irrigation on soil organic matter, soil microbial biomass and its activities in central Mexico. Biol. Fertile Soils, 31: 414-421.

Gleick, P.H. 2000. The World's Water 2000-2001. The Biennial Reports on Freshwater Resources. Island Press, Washington, DC, $315 \mathrm{pp}$.

GOB (Government of Bangladesh). 1997. Water Quality Standards for Drinking Water and Irrigation. Bangladesh Gazette Notification, Ministry of Environment and Forests, GOB.

Kadlec, R.H. and Knight R.L. 1996. Treatment Wetlands. Lewis Publisher, New York, p.893.

Kandiah A. 1990. Water quality management for sustainable agricultural development. Natural Resour. Forum, 14: $22-23$.

Michael, A.M. 1985. Irrigation: Theory and Practice. Vikas Publishing House Private Limited, New Delhi, India. p.689.

Pereira, L.S., Oweis, T. and Zairi, A. 2002. Irrigation management under water scarcity. Agric. Water Manage., 57: $175-206$.

Saleh, A.S., Salam, A. and Khalil, J. 2009. Effect of irrigation with reclaimed wastewater on soil properties and olive oil quality. Jordan J. Agril. Sci., 5: 128-141.

Shahinasi, E. and Kashuta, V. 2008. Irrigation water quality and its effects upon soil. BALWOIS Ohrid, Republic of Macedonia, Tirana Agricultural University, Tirana, Albania.

Tarenitzky, J., Golobati, Y. Veren, R. and Chen, Y. 1999. Wastewater effects on montmorillionite suspensions and hydraulic properties of sandy soil. Soil Sci., 92: 125-128.

UNESCAP (UN Economic and Social Commission for Asia and the Pacific). 1982. Section II: Sugar Industry - Industrial pollution control guidelines, Bangkok.

Vogeler, I. 2009. Effect of long-term wastewater application on soil physical properties. Water, Air and Soil Pollution, 196: 385-392. 